\title{
Lean and White-Collar Work: Towards New Forms of Industrialisation of Knowledge Work and Office Jobs?
}

\author{
Tobias Kämpf
}

ISF München, München, Germany, tobias.kaempf@isf-muenchen.de,

\section{www.isf-muenchen.de}

\begin{abstract}
After revolutionising manufacturing in the 1980s, the ideas of lean production are becoming increasingly significant for today's white-collar work. Drawing on extensive empirical fieldwork, this article shows the fundamental changes in knowledge and office work as a result of new lean concepts. Two case studies are compared: the implementation of lean in the administration of a traditional industrial company and the reorganisation of software development by combining lean with Agile methods in a leading IT company. Lean is becoming a pioneer for new forms of industrialisation of white-collar work. The spectrum extends from a 'factory approach' with rigid work flows in administration to new development models in knowledge-intensive areas that go well beyond Tayloristic approaches. Based on the possibilities of digitisation, lean opens up new ways for the valorisation of knowledge work in modern capitalism, best described with the Marxian notion of 'real subsumption' of labour under capital.
\end{abstract}

Keywords: Agile methods, industrialisation, knowledge work, lean, lean production, new production models, white-collar work

\section{Introduction: A New Wave of Lean in White-Collar Work}

The world of work is undergoing rapid change. Driven by digital transformation, many observers believe the nature of work itself must be rethought. Many Fordist-era certainties about the organisation of work are under scrutiny, not just in manufacturing but also in knowledge work. ${ }^{1}$ From administration to research and development $(R \& D)$, fundamental changes are occurring. The upheavals in whitecollar work exceed mere questions of automation or job losses (see Frey and Osborne 2013; Brynjolfson and McAfee 2012); instead, they suggest a fundamental restructuring of the labour process and work itself.

In this context, lean production concepts have acquired new significance. Since the 1980s, when the lean production methods of the Japanese automotive industry revolutionised production (Womack et al. 1990), companies have gathered broad experience with this new model. Now they are using these experiences to transfer lean concepts into their offices in a new way - a trend often called 'lean office', 'lean

\footnotetext{
1 'Knowledge work' is a common term used to denote work activities primarily devoted to generating knowledge. However, no generally accepted definition has been established. Mosco and McKercher (2007, x-xi) provide an overview of approaches, including a narrow definition that only encompasses "creative labour", wider definitions that include the handling and distribution of information, and broad approaches which include "all workers involved in the chain of producing and distributing knowledge products". In this article, a distinction will be made between medium-skilled office jobs in administration and highly-skilled knowledge work such as software development.
} 
engineering' or 'lean development'. In the past, companies mostly applied individual lean tools in offices as a limited measure to reduce costs, but nowadays companies apply strategic initiatives to reshape the processes and structures of entire business units with thousands of employees. The pioneers fall into two groups: large industrial corporations, which transfer established lean concepts to administration and R\&D, and major IT companies. In this knowledge-intensive industry, new forms of lean development, combining Agile development methods and ideas from lean production, represent a paradigm shift in software development (see e.g. Poppendieck and Poppendieck 2007; Boes and Kämpf 2014).

The fields now being updated with new lean concepts - such as R\&D, IT and software development and even administration - once occupied a special and privileged position in Fordist companies. They were only seen as secondary targets for rationalisation processes due to the limited number of workers compared to mass production facilities. In addition, traditional Taylorist rationalisation strategies never really "got hold of skilled white-collar work" (Littek and Heisig 1995, 373). Aside from bureaucratic approaches to administration, a managerial strategy of "responsible autonomy" prevailed in areas requiring high levels of qualification (Friedman 1977). However, the number of white-collar employees has grown continuously, and in many traditional industrial companies they now outnumber blue-collar workers. During the crisis of Fordism, this fast-growing white-collar world finally became the target of ongoing cost reduction, rationalisation programs and new strategies to intensify work (e.g. Keliher and Anderson 2010). It is no longer a mere appendix to manufacturing, but is in the centre of the capitalist production process and the commodification of human labour. As a consequence, the development of whitecollar work has become an important research issue for a critical theory of modern capitalism. From a sociology-of-work perspective a thorough analysis of rationalisation strategies and the white-collar labour process contributes to understanding contemporary capitalist societies as a whole: changes in the work world can take effect not only on the economy but also on the dynamics of class and even the political sphere.

Against this background, this article develops an empirical perspective on applying new lean concepts in knowledge work and office jobs. The primary focus is on how work processes in white-collar fields are changed by concepts such as lean, with a secondary focus on the consequences for employees. After an elaboration of the research perspective and an outline of the empirical approach, two case studies will be compared: the implementation of lean in the administration of an industrial company and the reorganisation of software development by combining lean with Agile methods in a leading IT company. Based on a critical discussion of the empirical findings, the final chapter argues that lean is a hallmark of a leap of productive forces in society and paves the way for new forms of industrialisation of white-collar work.

\section{From the Debate on Lean Production to the Industrialisation of White-Collar Work}

Industrialisation concepts such as lean production have revolutionised manufacturing processes since the 1980s. This trend began with the production models of the Japanese automotive industry. Following the influential study by Womack et al. (1990), these models started to receive widespread attention and were seen as the role models for lean production. This reputation is also reflected in a broad international and interdisciplinary scientific debate (see the overview by Holweg 
2007; Hines et al. 2004). Examples range from well-known studies on the Japanese automotive industry (Womack et al. 1990; Ohno 1988; Rother 2009; Jürgens 1995); to the German debate on the "new concepts of production" (Kern and Schumann 1987), where discussions focus on opportunities to end Taylorism and humanise work; to numerous empirical studies on lean elements in practice.

The essence of lean is subject to debate. Womack et al. assert that the central goal of achieving "perfection" in the sense of "continually declining prices, zero defects, zero inventories and endless product variety" is the "defining" difference from the "good enough" principle of traditional mass production (1990, 13f). This strategy of consistently eliminating waste is informed by a systemic view of the production process. This points towards the essence of lean: an "integrative approach" (Krafcik $1988,51)$ that provides a holistic perspective on the entire value chain. Every part of the value chain and the interplay between these parts is continuously assessed in terms of value creation.

From an industrialisation theory perspective this holistic view is crucial: where the Taylorist paradigm focuses on rationalising individual tasks, the rise of lean production sees a return to industrialisation concepts inspired by the idea of an overall process and the systemic integration of the whole value chain. Interestingly, this provides some important links to a Marxian interpretation of industrialisation, which is built upon a differentiation between 'manufacture' and 'large-scale industry'. Marx emphasises that in large-scale industry the labour process is no longer defined by the addition of individual "subjective" tasks but by a "total process" in which the "partial processes" are integrated "objectively" and bound together by the machinery (Marx 1976/1867). ${ }^{2}$ If one combines these basic assumptions with the concepts devised by Ohno (1988), the architect of the Toyota production system, an instructive interpretation of lean arises: the pillars of his approach - e.g. establishing a "flow of production", levelled and synchronised processes that work "just in time" and the "Kanban system", where the flow of information is processed in parallel to the flow of the assembly pieces - no longer appear to be limited tools for rationalisation, but part of a systemic approach which aims to organise production in the spirit of an integrated "objective" process (Marx 1976/1867). ${ }^{3}$

This comprehensive view on industrialisation and lean pays attention to the development of white-collar work. Seen from this holistic perspective, work areas outside production, such as research and development (R\&D), administration or marketing, are simply natural parts of the overall value chain and are therefore also subject to the methods and principles of lean production (see Womack et al. 1990, $104 \mathrm{ff}$ ). Thus it is frequently argued that lean can only reach its full potential when applied not just to manufacturing but also to the surrounding areas of knowledge

\footnotetext{
2 The full quote is as follows: "Nevertheless, an essential difference at once appears. In manufacture, it is the workers who, either singly or in groups, must carry on each particular process with their manual implements. The worker has been appropriated by the process; but the process had previously to be adapted to the worker. This subjective principle of the division of labour no longer exists in production by machinery. Here the total process is examined objectively, viewed in and for itself, and analysed into its constitutive phases. The problem of how to execute each particular process, and to bind the different partial processes together into a whole, is solved by the aid of machines, chemistry, etc." (Marx 1976, 501f).

${ }^{3}$ Against this backdrop it is hardly surprising that the Japanese engineers had a relatively positive attitude towards Fordist mass production and especially the idea of the assembly line (Fujimoto 1998).
} 
work (e.g. Liker and Morgan 2006). As a consequence, many companies quickly began to apply lean ideas in the office (see management literature, e.g. Productivity Press Development Team 2005; Association for Manufacturing Excellence 2007). However, results were modest and hardly comparable to the sweeping transformations in manufacturing. While principles such as the flow of production, the Kanban system or teamwork significantly transformed work processes in factories, no comparable operable lever was found in the white-collar world, where lean was understood as a management philosophy, a set of tools for incremental improvements or a simple cost-cutting strategy rather than a concept to establish new production models.

The new lean initiatives within industry and IT companies point towards a striking change: using lean, large-scale reorganisations of labour processes and organisational structures are now being advanced in the area of white-collar work. With the ongoing growth of white-collar work, comprehensive lean concepts gain new strategic relevance. Companies cannot limit themselves to small-scale improvements of single processes anymore, but develop ambitious and detailed roll-out plans for departments with several thousand employees. This is accompanied by an accelerating digitisation opening up new vantage points for reorganisation. From an industrialisation theory perspective, crucial research questions arise: what is the substance of this development in practice, and how is white-collar work changing? Are the industrial principles of lean - such as flow production - gaining new significance for white-collar employees and can they also open knowledge work towards industrialisation? In order to explore these questions properly, one must take the transformation of work and the experiences of employees into account: how do work processes change, what are the consequences for working conditions and how do employees experience the implementation of lean?

Addressing these research questions, Labour Process Theory provides an important theoretical framework. Following the debate on Braverman's famous study "Labour and Monopoly Capital" (1998, first published in 1974) this crucial approach to the sociology of work points out that a systematic and empirical account of concrete labour processes is vital for an analysis of capitalist societies. A particular focus is put on the question of how control is maintained in the labour process. Interestingly, the development of white-collar work already plays an important role in Braverman's initial study (1998; see Carter et al. 2011), although with a certain bias towards Taylorist approaches. The analytical perspectives developed in critical debate with Braverman - from Friedman's continuum between "responsible autonomy" and "direct control" (1977; 1990), to Edwards' differentiation between "simple, technical and bureaucratical control" (1979), through to Burawoy's analysis of "hegemonic control" (1979) - turned out to be particularly instructive for an analysis of white-collar work (see e.g. Barrett 2005). Moving beyond Taylorism they show, on the one hand, that there is not one paradigm of control but a complex interaction of different forms of control; on the other hand, they emphasise that employees are not just passive recipients of rationalisation strategies. Instead the labour process is "contested terrain" (Edwards 1979) actively shaped by workers in constant struggle.

With respect to the implementation of lean, the studies of Carter et al. (2011; 2013) in the public sector are particularly revealing. Using Labour Process Theory they show how the application of lean resulted in an assembly-line style of backoffice organisation, rather than job enrichment. The employees' scope for action was clearly reduced while their stress levels rose significantly (similar results are found in Esbenshade et al. 2016). In a complementary manner, Hodgson and Briand used 
individual software teams as examples to show that even in highly-educated environments, new agile work forms do not necessarily lead to more empowerment, but can act as the source of new hierarchies (2013). These results show that a careful analysis of work processes and control strategies is necessary to thoroughly understand the new lean initiatives in white-collar work. A differentiated perspective should not overlook the impacts of lean on the conditions for empowerment and the autonomy of employees.

\section{Methodology and Research Approach}

The empirical basis of the current article is drawn from several research projects employing qualitative research design to analyse the development of knowledge work and office jobs over the past 10 years. The most relevant source for this article is the research project Lean in the Office (funded by the Hans-Böckler-Foundation), which focused on new forms of lean. It produced 12 case studies, relying on a total of 192 interviews with managers, representatives from works councils and employees. The cases cover administration, R\&D and software development.

Considering the heterogeneity of white-collar work, it is necessary to perform a "comparative analysis" (Edwards 2007). The underlying hypothesis is that new lean concepts and the changes of labour processes vary according to the skill level of jobs. The comparative approach is based on the assumption that, especially in highly-skilled areas of white-collar work, new forms of industrialisation beyond Taylorist approaches are required. Therefore, two case studies were selected that enable a comparison of the practice of lean in areas with different qualification levels: administration (Case Study A) and software development (Case Study B). Most employees in Case Study A were moderately qualified, while the software developers from Case Study B were mostly university graduates with at least a bachelor's degree. In both cases it was possible to gather empirical data over the course of multiple years to gain insights into changes in work over time.

Both companies are pioneers for new lean concepts and provide insightful examples of a broad and comprehensive implementation of lean. Case Study A covers the reorganisation of administrative jobs in the financial services of a German industrial company. Two waves of data-gathering (2008-2009 and 2014-2015) produced 15 interviews: ten expert interviews (with representatives from management, the works council and trade union officials) and five in-depth interviews with employees. Case Study B involves a large European IT company where lean was implemented within the development department of over 10,000 employees. Between 2010 and 2015, it was possible to gather extensive data on the large-scale implementation and maturation of the new development model in multiple waves. This involved a total of 70 interviews with employees and 21 expert interviews with representatives from management and the works council.

The case study approach combined expert interviews (Trinczek 2009) with indepth interviews with employees. The expert interviews provided insights into the strategic context of the introduction of lean, while the in-depth interviews helped to analyse the implementation and practice of lean in employees' daily work. They also considered employees' subjective views and experiences. In order to achieve this, the employee interviews were conducted as "problem-centred interviews" (Witzel and Reiter 2012), following guidelines while still giving the interviewees leeway to focus on the issues most relevant to them. The expert interviews lasted 60-90 minutes, the employee interviews 90-120 minutes. All interviews were recorded, transcribed and individually evaluated. Using an inductive approach, the interviews were subject to 
the reconstruction of themes and patterns and were contrasted with the theory-laden assumptions of the research team. In order to systematically reflect developments in these cases over a multiyear survey period, an iterative research process was used to interweave the interviews from across the different survey points and to gradually concentrate these into valid and meaningful case studies.

\section{Case Study A: Lean and the Restructuring of Office Jobs}

Case study A focuses on a German company (Company A) from the metal and electronics industry with several hundred thousand employees. A pioneer of lean manufacturing, Company A also started to use lean to reorganise work outside production. In contrast to other companies where lean is implemented haphazardly in various individual departments, Company A followed a uniform and comprehensive roll-out plan, initiated by top management. This program focused on administrative areas, e.g. human resources, financial services and controlling. The implementation of lean was determined via collective agreement, bargained by the group works council and management at a company level.

\subsection{Shared Services as a Starting Point for Lean}

The comprehensive introduction of lean in Company A builds on a series of rationalisation activities and changes in administrative work processes. White-collar employees traditionally enjoyed privileged work conditions in the company. Stability, security and - despite Company A's deeply bureaucratic organisation - a certain degree of autonomy at individual workplaces were standard, even in many administrative jobs. For a long time, rationalisation, cost-cutting and the search for productivity gains focused on manufacturing. But the massive growth in white-collar jobs - more than half of all jobs in Germany today fall outside of production - and diminishing potential for productivity gains in production prompted a strategic reorientation. In 2006, a large-scale management initiative was launched that focused predominantly on the rationalisation of administrative activities. The goal of this programme was to cut one billion Euros in costs per year and reduce the number of employees in general and administrative areas by $20 \%$.

However, the volume of these downsizing efforts, which were accompanied by significant trade union protests, was not the whole story. The crucial factor was that this programme also made work processes in the office itself subject to fundamental changes. Most importantly, the concept of "shared services" (Bergeron 2003) was promoted. At first glance, this simply meant tasks and activities within HR or Finance and Controlling were standardised and centralised. The previous distribution of such tasks was inefficient, with departments in different locations working with different processes and standards. Homogenising these routines and centralising staff provided uniform services for the whole organisation.

Looking more deeply, the concept revealed extensive standardisation and digitisation of office jobs throughout the company. This resulted in the standardisation of the IT systems, an increased degree of digitisation (e.g. digital records or accounts) and the IT systems becoming the foundation for work processes. Work routines were meticulously documented within teams and departments. These were translated into standardised digital workflows that determined work through detailed requirements for work procedures and structured the division of labour along the entire value chain. Digital ticket systems organised the supply of tasks (e.g. checking an account) for each employee. Holistic job profiles with a diverse set of tasks were replaced with increased specialisation, narrower task ranges and fewer opportunities 
for employees to use their unique competencies. This new exchangeability was perceived as a loss of recognition among employees: "[...] you feel like a number, a number that can be exchanged at any time, whose work can be done by anyone else in the world exactly like you'd do it" (A-7).

\subsection{A Comprehensive Roll-Out of the Lean Office and its Consequences for Employees}

Building on these changes, lean implementation was promoted. Following the previous wave of downsizing, lean fulfilled a special strategic purpose. Productivity was paramount, as the same administrative workload was supposed to be completed by fewer employees. Against this background, management established the main targets of lean as eliminating waste and improving processes to increase efficiency internal benchmark analyses targeted $30 \%$ reduction of waste in administration. This course of action was itself remarkable: lean was not used as a tool to leverage rationalisation effects and cut costs by downsizing as a consequence of productivity gains; instead, staff numbers were reduced in advance. Consequently, introducing lean and increasing productivity appeared to be the only choice to help remaining staffers struggling with an overload of tasks.

Lean was implemented across the organisation in a top-down manner and supported by an internal consultancy unit. This unit trained 'lean agents' in individual departments over several months who functioned as multipliers throughout the company. The implementation of lean followed a uniform three-phase-model. The starting point were smaller lean workshops and improvement projects - measures such as $5 \mathrm{~A}$ workshops and joint structuring of the workplace were designed to make employees open to lean ideas. Next, 'shop floor management' methods were introduced into the teams - including a shop floor board on which core work procedures were visualised on a day-to-day basis, fundamental for team management. Finally, central work procedures and interdepartmental processes were evaluated and reorganised based on extensive value stream analyses.

In particular, shop floor management fundamentally changed work realities. Within the Finance Department, all team members and the team-leader met every morning at the shop floor board for a daily stand-up meeting. Everybody had to explain the processing status of their tasks from the previous day and state what tasks were planned for that day. Team members had to state how much time they allotted to each of their tasks and how much time it took them to complete their tasks from the previous day. All tasks were visualised on the shop floor board accordingly. This ensured transparency, with the performance of each team member made available to management and to all other team members. Based on this information, the KPIs for the team were discussed and visualised at the board each day. This made the productivity of the entire team transparent and provided an important vantage point for managerial control and the team's self-organisation.

The introduction of lean accelerated the standardisation of work processes. Two strategies were employed. The first was workplace observations, which are analogous to production. Internal consultants observed employees - sometimes over the course of multiple days - and used this as a basis to develop process models and value stream analyses. Employees were also asked to define 'optimal' workflows for certain tasks and to document these in a 'standard worksheet'. Knowledge gained through individual experience was thus transferred to standard processes and made available for other colleagues. Employees reported that their work had changed significantly, that more homogenous work routines were developing and that their 
tasks became simpler. However, unlike the monolithic processes of the past, the new processes were now under constant review via the team's daily shop floor meetings. Thus, the teams themselves were thought to be drivers of the continuous improvement process, enabling flexible work routines and a learning organisation.

From an employee perspective, lean changed the content of their work significantly. The trends already initiated by shared services continued: broadlydefined areas of responsibility were replaced by increasing specialisation and a stricter division of labour. Individual autonomy was reduced through standardisation of processes and the simplification of many tasks (similar results are found in Carter et al. 2011; Esbenshade et al. 2016). This simplification was often perceived as a devaluation of work. When looking at the data, it was particularly striking how shop floor management and the new transparency were experienced by employees. These practices placed new pressures on team members and were reported to be a burden:

The next day you automatically adopt a defensive attitude: Why you couldn't do it. Why you only planned five hours to do it, when in the end it took eight. Yes, there's definitely an attitude of justification... and with us it's just being shown. It's always in your face, what you still have left to do. And it's very stressful, at least for me. [...] I have a different set of tasks from my colleagues, and they can't really understand that I sometimes sit in front of Excel for three hours. And I sometimes feel stupid - and it's not even related to my colleagues, but because I'm also thinking about how I can explain this in front of the board the next morning $(\mathrm{A}-10)$.

The quote demonstrates the dynamic that developed as a result of the transparency of the daily stand-ups. The employees felt they had to justify how much time they allotted to their tasks - and how long it actually took them. Notably, zones of uncertainty ("my colleagues [...] can't understand") were not used to secretly slip in extra time into work plans. Instead, employees seemed to give themselves less time for their tasks - in order to not attract negative attention - and therefore put pressure on themselves to meet tight, self-imposed deadlines.

The interplay between lean and shared services fundamentally changed the work processes in the department. Shared services established the framework for the digitisation of workflows and standardisation of processes, while lean was used to increase productivity subsequently. Lean was supposed to further drive standardisation efforts and continue process optimisation, while shop floor management and teamwork were employed to dismantle individual silos and to develop a new level of transparency. It is clear that the design of the daily stand-ups - visualising individual performance and working times - created a dynamic of intensified work and increased performance pressure.

\section{Case Study B: Lean, Agile and the Restructuring of Software Development}

Case Study B focuses on a European IT company (Company B) with tens of thousands of employees, more than 10,000 of whom worked in various software development centres around the world. Since the end of the 1980s, Company B has grown rapidly into a global, professionally-structured company. To manage this ongoing growth, bureaucratisation of work processes within software development was promoted. However, the paradigm of the classic 'waterfall project' pushed the limits of an increasingly complex organisation and ever-shorter innovation cycles. 
Major efforts to reform project management and controlling only led to more organisational overhead - with no increase in quality, speed or planning ability. In order to handle the increasing complexities of an ever-growing organisation, and not specifically to reduce costs, Company B started to develop a new approach for software development. The approach combined Agile methods and lean development, and it fundamentally reorganised work processes in a development division with thousands of employees.

\subsection{Lean as a New Development Model}

The starting point for the new development model were experiments using so-called Agile methods. These Agile methods, such as Scrum or pair programming, were originally developed at the end of the 1990s as a grassroots movement in the software community to counter the bureaucratic waterfall projects of large IT companies (Beck et al. 2001). ${ }^{4}$ This was based on the observation that the complex ex-ante planning of complete software projects - which ultimately relied on a separation between planning and execution - hardly ever worked in practice. Instead, Scrum capitalised on breaking down the development process into shortcycle development intervals - so-called 'sprints' - of two to four weeks. At the end of every sprint lies the development of 'usable software', which can then be iteratively developed into the final software product in successive further sprints. This concept relies on pronounced customer orientation, embodied by the role of the so-called 'Product Owner', and on strong empowerment of the development team, embodied by the role of the 'Scrum Master'.

Against this backdrop, it is understandable that the roots of the new development model can be traced back to Company B's developer community. To counter increasing bureaucratisation, the developers established a grassroots initiative to experiment with Agile development methods. Even though pilot projects using Scrum proved successful - especially in terms of quality and speed - top management were initially sceptical. The breakthrough only came once Scrum was combined with ideas from lean production. Lean principles were seen as necessary to scale the new development concepts and roll them out across entire departments. Second, lean as an established rationalisation method - provided these new development concepts with a narrative that was compatible with top management's ideas and freed them from association with grassroots, 'anti-management' movements. With the support of top management and a consultancy firm, the new development concept was then rolled out globally throughout Company B over a period of two years. ${ }^{5}$ This rapid change was also mirrored in a paradigm shift in leadership: the role of project managers was abolished, the manager-staff ratio was increased from 1:10 to $1: 30$ and the positions of Scrum Master and Product Owner were created.

This new development approach had three central pillars. First, development work was organised as a synchronised and clocked value chain. This was based on the short cycle development intervals inherent to Scrum. Depending on the development unit, two- and four-week sprints were the new standard. Since the endpoint of the sprint applied equally to all teams in a specific area, a common 'takt' was created. As such, the work of many different software teams became interwoven in a new way. This was also based on the fact that integration and compatibility

\footnotetext{
${ }^{4}$ A history and an overview on Scrum practices can be found in Sutherland (2012).

${ }^{5}$ As in Case Study A, the implementation of lean was determined via collective agreement at company level.
} 
testing became an early process step. The modern development environment allowed highly automated testing and integrating procedures along with a joint just-intime delivery of 'usable software' by all teams at the end of each sprint. In this way, Company B could reorganise the interfaces between teams and the handover of software packages and implement a system that establishes "production flow" (Ohno 1988).

Second, Company B managed to break down complex software into programming tasks that allow large development projects to be organised collaboratively without systematically separating the process of software specification from actual coding. After establishing the features of the software, a rough list of items - the backlog was created and dispersed between the various teams. It was essential that the precise description of the individual items and the prioritisation of tasks were now performed iteratively from sprint to sprint. This was the responsibility of the new Product Owner role. As several teams usually worked on each project, a pyramid structure of Product Owners was established to organise collaboration between teams following the 'Scrum of Scrums' principle. This organisational structure provided a new level of transparency and increased opportunities for managerial control (see also Barrett 2005). While development work under the previous system was normally a 'black box', the sprint intervals with their clearly defined items in the backlog allowed outsiders to assess the status of any project in two-to-four week intervals.

Third, Company B no longer relied simply on individual software developers, but the 'empowered team' became the nucleus of the new development model. The socalled 'team of ten' was understood as a self-organising autonomous unit with a great degree of autonomy in its daily work. According to Scrum, each team could decide for itself how many items from the backlog it could process and how the software should be programmed. The focus on team work represented a shift from the principle of individual expertise to the predominance of collective knowledge domains. Thus, team structures were characterised by a strong emphasis on sharing knowledge and creating transparency. For example, teams now met daily at a standup meeting, the Daily Scrum. There, the team members informed each other about the status of their tasks and had the opportunity to ask for assistance.

\subsection{The Transformation of Work and the Employee Perspective}

From an employee perspective, introducing lean development changed daily work routines immensely. In particular, the synchronised team schedule and sprints altered the rhythm of daily work. Even though the typical peaks before release decreased, the overall time buffers were reduced. The imponderables of software development could no longer be mitigated through long project runtimes and were felt directly by the developers. In addition, developers and teams no longer developed within their own silos, but were entangled in a web of interdependencies as a result of organisation-wide synchronisation. ${ }^{6}$ Instead of being exclusive to release time, these inter-organisational interdependencies now determined the daily

${ }^{6}$ One developer described the new working conditions as follows: "You don't work in a silo any more. You don't have a list of tasks that are specifically for you. Instead, there are a lot of tasks under my responsibility that other people are working on, too. They have a huge communication effort towards me now. Sometimes I have to create the preconditions so these people can process the tasks. So you have a greater dependency on each other which increases stress levels. When you were working in a silo, that just gave you fewer interaction points [...] and you could decide your own speed" (B-61). 
routine of many teams due to short development cycles. Analogous to just-in-time production, late delivery of code or unresolved interconnections now escalated faster and more seriously within the development process.

By breaking up the individual silos, Company B also increased the transparency of development work. Developers increasingly had to act and interact within public spaces. Regular team meetings like the Daily Scrum, as well as providing a platform to present project results, were predominantly used to communicate individual work progress and the status of individual tasks. This was a concern for employees, who reported that they had to 'reveal' or 'explain themselves'. One developer described how this increased work pressure:

Yes, [you have to] work longer hours. During your work you just feel a lot more pressure. Because you have to justify or explain yourself every day in the Daily Scrum. What did I do? What was my problem? What am I going to do today? So you're permanently under some kind of surveillance. And there's that permanent pressure to get it done. [...] when I have to explain myself in front of six colleagues every morning, justify what I managed to do yesterday, that is quite different from when I get asked by someone after three months: 'Hey, could you show me your application?' (B-44).

This example shows how these transparent working methods were interpreted as a threat and a sign of increased "surveillance". Furthermore, the empirical investigation revealed that both conflicts within management and the potential for conflicts within teams ('peer group pressure') increased significantly (on conflicts about the introduction of team work see Thursfield 2015).

Even under the old production system, software developers had stressful working conditions. With lean, however, employees voiced new concerns over an increasing pressure and a new 'permanent stress' (B-50). The lack of team empowerment was a particular driver (Boes and Kämpf 2014). While the empirical work identified some areas where teams now had more leeway, other areas showed the opposite trend: contrary to the initial ideas behind Scrum, employees testified that they could no longer define their workload and had less autonomy. Consequentially, interviewees complained about an environment where they only processed backlog items, like an 'assembly line'. The loaded question 'Are we just assembly line workers?' came up many times during the interviews. Without empowerment, the transformation of work was perceived as devaluation and a loss of recognition. As stated by one developer:

Stress levels will rise. And we're probably going to see an industrialisation of development, in a sense that eventually the software process will be like building a car. [...] The human element is abandoned. And for me that is the hallmark of industrialisation (B-42).

\section{Discussion and Conclusions}

Both case studies provide insights on fundamental changes of work processes driven by the implementation of lean. From an industrialisation theory point of view, they reveal new concepts and strategies to turn not only office jobs (Company $A$ ) but even highly-skilled software development work (Company B) towards industrial processes. By implementing industrialisation concepts such as lean in white-collar work, the idea of organising labour like an integrated "objective process" (Marx 1976/1867) is taking shape outside of manufacturing in new ways. 


\subsection{Comparing the Cases: No One Best Way for Industrialising White-Collar Work}

Comparing the two cases supports the initial assumption that a differentiation between office jobs and highly-skilled software development is necessary. Administrative areas within Company A are defined by a shared services concept and rigid work flows, which grant employees limited autonomy. As 'digital assembly lines' they bear resemblance to the analysis of Carter et al. (2011) and even to Tayloristic approaches. The combination of lean and Agile methods in software development within Company B stands in stark contrast to Company A's 'factory approach'. It is an important example of how industrial processes in white-collar work can be designed beyond Tayloristic approaches and without eliminating the intellectual potential of knowledge workers. Software development has many creative elements, so mere standardisation of tasks is insufficient. Instead, synchronising teams and integrating their work results over short cycles ('usable software') creates an integrated value chain, while preserving a high degree of autonomy and empowerment within some teams. The most important element of this approach is breaking up each developer's silo and putting a new focus on teamwork. As such, the conditions for 'responsible autonomy' and the mode of control in the labour process have changed. On the one hand, transparency in work processes creates even new options for 'direct control'. On the other hand, the team itself becomes a potential source of control and a central component of a multilayered configuration of control (see Barrett 2005).

In considering the issue of employee participation, a comparative analysis is also revealing. For Company $B$, the realisation of the new development model depends on active employee participation. Thus empowering the teams is an essential conceptual component of the new approach, despite often being neglected in practice. In Company $A$, in contrast, there is no notion of empowerment at any level. This is also reflected in the different implementation processes. While Company $A$ rolled out lean in a top-down process, Company B emphasised employee involvement, starting from an employee grassroots initiative. For these developers, Agile methods had a positive connotation derived from their original criticism of the bureaucratic waterfall model. Thus, the prospect of deformalisation of development work was a precondition for active employee involvement. However, the plans and labels changed gradually: 'Agile' became 'lean and Agile' and ultimately just 'lean'. Following the argument by Boltanski and Chiapello, the company managed to incorporate the "artist's critique" (2005) of the developers to transform work routines towards a new industrialised development approach.

\subsection{Digital Transformation as a Catalyst for Lean in White-Collar Work}

The case studies show that the implementation of lean within white-collar work reaches a new quality. Unlike past applications, lean now involves substantial transformation of labour processes. Considering the long history of lean, it is worth asking why lean is now achieving new significance outside of traditional production areas and how it has become a key tool for the reorganisation of white-collar work towards industrial processes.

The case studies demonstrate that it is crucial to consider the ongoing digitisation of labour processes as a key starting point (e.g. Boes et al. 2017b; Fuchs 2014; Huws 2014). In both administration and software development, employees are working with digitised work objects which are processed in continuous IT systems. The digital 'information space' is thus becoming a real "space of production" (Boes et al. 2017a). The "stream of paper" described by Braverman $(1998,208)$ is now turning 
into a digital 'flow of information'. This allows concepts such as flow principles and the idea of an integrated value chain in which individual work steps are synchronised without waste to be applied in offices in a whole new way. To transform IT-based tasks into standardised workflows, Company A unified their IT systems within the shared services program - a development mirrored in Company B, where modern development environments and systems provide the foundations for a new model. Using these systems, code produced by multiple developers can be tested automatically before being integrated into a joint software product, even on a daily basis if needed. Not only do developers cease working in separate silos - they now also contribute to a truly interlinked, collective labour process. Thus, these IT systems are an essential prerequisite for transforming the development process into a synchronised industrial value chain.

Still, it is essential not to attribute work changes solely to digitisation. Following the argument put forward by Spencer (2017), such a simple reification fails to consider complex organisational dynamics and social contradictions that determine the shape of production systems. Technology alone cannot define a clear work process. Reorganising white-collar work and generating a truly functional value chain from the digital 'flow of information' requires consideration of organisational concepts ranging from work organisation on the shop floor to overall configuration of the organisation, management and leadership approaches. From that point of view the case studies show that lean concepts offer important 'answers' for management in this regard. First, they contain specific tools such as value stream mapping or shop floor management. Second, they also provide theoretical concepts for the design of industrial value chains as integrated processes. Third, they convey a degree of authority, as there are many empirical examples of restructuring industrial manufacturing following lean principles.

Based on the new possibilities of digitisation, lean is becoming a strategic lever for companies to transform work processes in offices and knowledge work towards industrialisation. Company A used lean to advance its shared services concept towards a 'digital assembly line' and gain productivity as processes improve. For Company B, lean provided a way to scale Agile methods and establish a new industrial production model throughout the entire development department. At the same time, lean was used in both cases to enhance transparency in the labour process of its white-collar staff and to create a new configuration of control. It is striking that neither company relied solely on the visibility that emerges with digital work environments and the corresponding opportunities for direct or technical control. Instead, using lean transparency was deliberately created as a social process at team level and through the organisation of interactions and collaboration within teams. Shop floor management, stand-ups and Daily Scrums help to produce transparency by institutionalising daily discourse, and thus become new components of the control of white-collar work.

\subsection{Knowledge Work becomes Real Wage Labour: From New Forms of Industrialisation to a New Phase of Capitalism}

Obviously, the working conditions of white-collar work are undergoing fundamental changes. Both case studies reveal rising stress levels, a growing feeling of a devaluation in work, a loss of recognition and new insecurities among the employees. These developments show clear signs of an "intensification of work" (Keliher and Anderson 2010). However, from a conceptual perspective, industrialisation goes beyond an intensification of work. Marx considered industrialisation as a new 
principle for the organisation of production processes, which changes society as a whole. Above all, the transition from craft production to industrial production enabled the "real subsumption" (Marx 1976/1867) of manual labour under capital. Being an "objective process", the labour process could now systematically be subordinated to the valorisation of capital and the conditions of surplus value production. The real subsumption of blue-collar work and the new quality of valorisation of human labour became the foundation for the development of industrial capitalism from the 19th century onwards.

Diverging trajectories for manual and intellectual labour were constitutive to subsequent capitalist formations. Industrialisation focused on blue-collar work, while major parts of white-collar work didn't really fit with traditional industrialisation concepts. Case studies A and B are examples for a new development: they show how new forms of industrialisation are being implemented, now targeting even knowledge work. The industrialisation of labour processes allows companies to reduce their dependence on individual employees. As both case studies reveal, the breakdown of individual silos and the loss of "areas of uncertainty" in labour processes (Crozier and Friedberg 1981) undermine the individual power resources of workers and pave the way for the establishment of new forms of control. At the same time, unlike in traditional Tayloristic approaches, the subjective elements of knowledge work are not neglected. Instead, we can observe a more efficient, systemic and industrialised use of the subjective activities of knowledge workers whose labour has so far often only been 'formally' integrated into the capitalist production process. It is on the basis of being incorporated into an objective process that a growing share of knowledge work is targeted by new forms of industrialisation. From a theoretical perspective they become a new basis for a 'real subsumption' of knowledge work.

As the history of industrial capitalism indicates, the transformation processes from formal subsumption to real subsumption have been crucial for the development of capitalism (see Harvey 2018; Hardt and Negri 2018; Fuchs 2018). In terms of a "Landnahme" (Harvey 2003; Dörre and Haubner 2018) ${ }^{7}$ the industrialisation of knowledge work is tapping a new source of capitalist valorisation now. It becomes a driving force of a new phase of capitalism, which we call "informatised mode of production" (Boes and Kämpf 2018). The starting point of this process is digitisation and the development of productive forces. However, a differentiated, nondeterministic perspective is needed here. It is important to consider that the Marxian notion of productive forces does not refer solely to technological developments such as digitisation; much more, at the very core is human labour power. The case studies reveal the complex interplay of technology and what Marx calls "forms of cooperation" (1976/1867). They show that, on an intermediate level, managerial strategies and production concepts such as lean are needed to really transform labour processes. The industrialisation of knowledge work is not a determined technological process, in which knowledge workers are just passive recipients. It is much more a contradictory and open social process, shaped by daily working practice, power relations and conflict. As seen in Case Study B, knowledge workers can even prompt the reorganisation process initially. The growing importance of concepts such as 'team empowerment' is not simply an ideological twist of the

${ }^{7}$ The discussion on 'Landnahme', initially based on the thoughts of Rosa Luxemburg on capital accumulation, suggests that the development of capitalist societies relies on the constant exploitation of new sources of value, not or not fully commodified so far (see Dörre and Haubner 2018, 72ff). 
management, but reveals that the configuration of work processes is negotiated permanently in the new development model and is an object of ongoing struggle. These struggles around team empowerment give a glimpse on possible vantage points for resistance and new power resources for knowledge workers, to counter and to limit the subsumption of labour under capital.

The effects caused by the implementation of new forms of industrialisation are not restricted to the immediate sphere of work. Moreover, they affect capitalist societies as a whole, and even the political sphere. An example is the rapid rise of new rightwing parties such as the AfD in Germany. This development cannot be understood without taking into account the anxieties and the growing fear of status loss among the middle class (see Nachtwey 2018), which is to a large extent comprised of whitecollar workers. Especially, the arguments by Eric Olin Wright on the class location of knowledge work (e.g. 1997) remind us that the origins of shifting social structures of class are changes of the labour process itself. The Fordist era, which was characterised by the fact that crucial segments of white-collar work were only 'formally' subsumed under capital, has seen the rise of the middle class and a growing "zone of integration" (Castel 2003). The industrialisation of knowledge work points to a different direction and opens up new social divisions among this previously stable and privileged social stratum. Members of the middle class who are able to protect their 'zones of uncertainty' in the labour process can hope to retain their privileged conditions of work and life, or even improve them. But the same does not apply to the growing groups of knowledge workers who are confronted with industrialised labour processes, transparent work routines and new forms of control. The decline of the middle class, with its characteristic "fear of falling" (Ehrenreich 1989), or what Randy Martin calls "the decomposition of the professional managerial class" $(2015,260)$ gets a new crucial driving force. It is no longer primarily based on indirect effects, the neoliberal deregulation of labour markets or economic and financial crisis. Rather, it is fundamental transformations in the sphere of work itself that turn knowledge work into 'real' wage labour now (Boes and Kämpf 2018).

\section{References}

Association for Manufacturing Excellence. 2007. Lean Administration: Case Studies in Leadership and Improvement. New York: Productivity Press.

Barrett, Rowena. 2005. Managing the Software Development Process: Direct Control, Time and Technical Autonomy. In Management, Labour Process and Software Development: Reality Bites, edited by Rowena Barrett, 76-99. London: Routledge.

Beck, Kent, Mike Beedle, Arie van Beenekum, Alistair Cockburn, Ward Cunningham, Martin Fowler, James Grenning et al. 2001. Manifesto for Agile Software Development. Accessed June 4, 2018. http://www.agilemanifesto.org

Bergeron, Bryan. 2003. Essentials of Shared Services. New Jersey: Hoboken.

Boes, Andreas and Tobias Kämpf. 2018. Informatization as Force of Production. In Capitalism and Labor. Towards Critical Perspectives, edited by Klaus Dörre, Nicole Mayer-Ahuja, Dieter Sauer and Volker Wittke, 283-301. Frankfurt: Campus.

Boes, Andreas and Tobias Kämpf. 2014. Agile Methods, Lean Development and the Change of Work in Software Development. In Future Business Software, edited by Gino Buretti, Thomas Feld, Lutz Heuser, Joachim Schnitter and Christian Weibel, 83-92. Cham: Springer.

Boes, Andreas, Tobias Kämpf, Thomas Lühr, Barbara Langes and Alexander Ziegler. 2017a. Cloud \& Crowd: New Challenges for Labour in the Digital Society. tripleC: Communication, Capitalism \& Critique. Open Access Journal for a Global Sustainable Information Society. 15 (1): 132-147. 
Boes, Andreas, Tobias Kämpf, Barbara Langes and Thomas Lühr. 2017b. The Disruptive Power of Digital Transformation. New Forms of Industrialising Knowledge Work. In The New Digital Workplace: How New Technologies Revolutionise Work, edited by Kendra Briken, Shiona Chillas, Martin Krzywdzinski and Abigail Marks, 153-173. London: Palgrave.

Boltanski, Luc and Ève Chiapello. 2005. The New Spirit of Capitalism. London: Verso.

Braverman, Harry. 1998/1974. Labor and Monopoly Capital: The Degradation of Work in the Twentieth Century. New York: Monthly Review Press.

Brynjolfson, Erik and Andrew McAfee. 2011. Race Against the Machine. How the Digital Revolution is Accelerating Innovation, Driving Productivity and Irreversibly Transforming Employment and the Economy. Lexington: Digital Frontier Press.

Burawoy, Michael. 1979. Manufacturing Consent: Changes in the Labour Process under Capitalism. Chicago: Chicago University Press.

Carter, Bob, Andy Danford, Debra Howcroft, Helen Richardson, Andrew Smith and Phil Taylor. 2013. 'Stressed out of my box': Employee Experience of Lean Working and Occupational III-Health in Clerical Work in the UK Public Sector. Work, Employment and Society 27 (5): 747-767.

Carter, Bob, Andy Danford, Debra Howcroft, Helen Richardson, Andrew Smith and Phil Taylor. 2011. 'All they lack is a chain': Lean and the New Performance Management in the British Civil Service. New Technology, Work and Employment 26 (2): 83-97.

Castel, Robert. 2003. From Manual Workers to Wage Laborers: Transformation of the Social Question. New Brunswick: Transaction Publishers.

Crozier, Michel and Erhard Friedberg. 1981. Actors and Systems: The Politics of Collective Action. Chicago: Chicago University Press.

Dörre, Klaus and Tine Haubner. 2018. Landnahme through Tests: A Useful Concept for the Sociology of Work. In Capitalism and Labor: Towards Critical Perspectives, edited by Klaus Dörre, Nicole Mayer-Ahuja, Dieter Sauer and Volker Wittke, 71-112. Frankfurt: Campus.

Edwards, Paul. 2007. The State of the Labour Process Debate after 25 Years: Some Reflections from Industrial Relations and Industrial Sociology. $25^{\text {th }}$ International Labour Process Conference, Amsterdam.

Edwards, Richard. 1979. Contested Terrain. London: Heinemann.

Ehrenreich, Barbara. 1989. Fear of Falling: The Inner Life of the Middle Class. New York: Pantheon Books.

Esbenshade, Jill, Matt Vidal, Gina Fascilla and Mariko Ono. 2016. Customer-driven Management Models for Choiceless Clientele? Business Process Reengineering in a California Welfare Agency. Work, Employment and Society 30 (1): 77-96.

Frey, Carl and Martin Osborne. 2013. The Future of Employment: How Susceptible are Jobs to Computerization? Oxford: Oxford Martin.

Friedman, Andrew. 1990. Managerial Strategies, Activities, Techniques and Technology: Towards a Complex Theory of the Labour Process. In Labour Process Theory, edited by David Knights and Hugh Willmot, 177-208. London: Macmillan.

Friedman, Andrew. 1977. Responsible Autonomy versus Direct Control over the Labour Process. Capital and Class, 1 (1): 43-57.

Fuchs, Christian. 2018. Universal Alienation, Formal and Real Subsumption of Society Under Capital, Ongoing Primitive Accumulation by Dispossession: Reflections on the Marx@200-Contributions by David Harvey and Michael Hardt/Toni Negri. In tripleC: Communication, Capitalism \& Critique. Open Access Journal for a Global Sustainable Information Society. 16 (2): 454-467.

Fuchs, Christian. 2014. Digital Labour and Karl Marx. London: Routledge.

Fujimoto, Takahiro. 1998. The Toyota System in the 1950s. Social Science Japan 12: 13-15. 
Hardt, Michael and Toni Negri. 2018. The Powers of the Exploited and the Social Ontology of Praxis. tripleC: Communication, Capitalism \& Critique. Open Access Journal for a Global Sustainable Information Society. 16 (2): 415-423.

Harvey, David. 2018. Universal Alienation and the Real Subsumption of Daily Life under Capital: A Response to Hardt and Negri. tripleC: Communication, Capitalism \& Critique. Open Access Journal for a Global Sustainable Information Society. 16 (2): 449-453.

Harvey, David. 2003. The New Imperialism. Oxford: Oxford University Press.

Hines, Peter, Matthias Holweg and Nick Rich. 2004. Learning to Evolve: A Review of Contemporary Lean Thinking. International Journal of Operations \& Production Management 24 (10): 994-1011.

Hodgson, Damian and Louise Briand. 2013. Controlling the Uncontrollable: 'Agile' Teams and Illusions of Autonomy in Creative Work. Work, Employment and Society 27 (2): 308325.

Holweg, Matthias. 2007. The Genealogy of Lean Production. Journal of Operations Management 25 (2): 420-437.

Huws, Ursula. 2014. Labor in the Global Digital Economy. New York: Monthly Review Press. Jürgens, Ulrich. 1995. Lean Production in Japan: Myth and Reality. In The New Division of Labour: Emerging Forms of Work Organisation in International Perspective, edited by Wolfgang Littek and Tony Charles, 349-366. Berlin: de Gruyter.

Keliher, Clare and Deirdre Anderson. 2010. Doing more with less? Flexible working practices and the intensification of work. Human relations 63 (1): 83-106.

Kern, Horst and Michael Schumann. 1987. Limits of the Division of Labour. New Production and Employment Concepts in West German Industry. Economic and Industrial Democracy 8 (2): 151-176.

Krafcik, John F. 1988. Triumph of the Lean Production System. Sloan Management Review 30 (1): 41-52.

Boes, Andreas, Tobias Kämpf, Barbara Langes and Thomas Lühr. 2013-2016. Lean Office (Lean im Büro - Neue Industrialisierungskonzepte im Büro und ihre Folgen für Arbeit und Beschäftigte). Research Project funded by the Hans-Böckler-Foundation.

Liker, Jeffrey K. and James M. Morgan. 2006. The Toyota Way in Services: The Case of Lean Product Development. Academy of Management Perspectives 20 (2): 5-20.

Littek, Wolfgang and Ulrich Heisig. 1995. Taylorism Never Got Hold of Skilled White-Collar Work in Germany. In The New Division of Labour. Emerging Forms of Work Organisation in International Perspective, edited by Wolfgang Littek and Tony Charles, 349-366. Berlin: de Gruyter.

Martin, Randy. 2015. What has become of the professional managerial class? In Transforming Classes - Socialist Register 2015, edited by Leo Panitch and Greg Albo, 250-269. London: Merlin Press.

Marx, Karl. 1976/1867. Capital: A Critique of Political Economy: Vol. I: Capitalist Production. Harmondsworth: Penguin.

Mosco, Vincent and Catherine McKercher. 2007. Introduction: Theorizing Knowledge Labor and the Information Society. In Knowledge Workers in the Information Society, edited by Catherine McKercher and Vincent Mosco, vii-xxiv. Lanham, MD: Rowman.

Nachtwey, Oliver. 2018. Germany's Hidden Crisis: Social Decline in the Heart of Europe. London: Verso.

Ohno, Taiichi. 1988. The Toyota Production System: Beyond Large-Scale Production. Portland: Productivity Press.

Poppendieck, Mary and Tom Poppendieck. 2007. Implementing Lean Software Development: From Concept to Cash. Upper Saddle River, NJ: Addison-Wesley.

Productivity Press Development Team. 2005. The Lean Office: Collected Practices and Cases. New York: Productivity Press.

Rother, Mike. 2009. Toyota Kata: Managing People for Improvement, Adaptiveness and Superior Results. New York: McGraw Hill Professional. 
Spencer, David. 2017. Work in and beyond the Second Machine Age: The Politics of Production and Digital Technologies. Work, Employment and Society 31 (1): 142-152.

Sutherland, Jeff. 2012. The Scrum Papers: Nut, Bolts, and Origins of an Agile Framework. Accessed June 5, 2018. http://jeffsutherland.org/scrum/ScrumPapers.pdf

Thursfield, Denise. 2015. Resistance to Teamworking in a UK Research and Development Laboratory. Work, Employment and Society 29 (6): 989-1006.

Trinczek, Rainer. 2009. How to Interview Managers? Methodical and Methodological Aspects of Expert Interviews as a Qualitative Method in Empirical Social Research. In Interviewing Experts, edited by Alexander Bogner, Beate Littig and Wolfgang Menz, 203-216. Basingstoke: Palgrave Macmillan.

Witzel, Andreas and Herwig Reiter. 2012. The Problem-centred Interview. London: Sage. Womack, James, Daniel Jones and Daniel Roos. 1990. The Machine That Changed the World: The Story of Lean Production. New York: MacMillan.

Wright, Eric Olin. 1997. Class Counts: Comparative Studies in Class Analysis. Cambridge: Cambridge University Press.

\section{About the Author}

Tobias Kämpf,

Tobias Kämpf, DPhil, is senior researcher at the Institute for Social Science Research in Munich (ISF München) and lecturer at the Friedrich-Alexander-University ErlangenNuremberg. His research focus ranges from the digitisation of modern labour societies and the future of work to new globalisation processes and the changing working conditions of white-collar work. He is editor of 'Arbeit - Zeitschrift für Arbeitsforschung, Arbeitsgestaltung und Arbeitspolitik'. 